\title{
Dissipation de l'énergie sur les ouvrages hydrauliques de haute chute par le dissipateur à double effet
}

\section{Dissipation of energy at high head hydraulic structures by double jet dissipator}

PAR

\author{
H. L. UPPAL \\ M. Sc., Ph. D., F.N.I.
}

\begin{abstract}
La dissipation d'énergie $\dot{a}$ l'aval des ouvrages hydrauliques tels que évacuateurs, seuils, déversoirs, etc., est en général obtenue par la formation' d'un ressaut. Ceci requiert une profondeur d'eau minimum à l'abal, profondeur qu'il n'est pas possible d'obtenir dans tous les cas. Un nouveau type de dissipateur $\dot{\alpha}$ double effet a donc été mis au point.

C'est un déflecteur crénelé dont les interstices se prolon'gent vers l'aval afin de former une seconde série de déflecteurs. Il est installé en un point convenable sur le parement d'un évacuateur ou d'un seuil. La nappe s'écoulant le long du parement est fractionnée en un grand nombre de jets qui réagissent les uns sur les autres dans l'air et dissipent de l'énergie. Une caracteristique importante du dissipateur $\dot{a}$ double effet est qu'il ne présente aucune saillie d̀ l'intérieur du jet à grande vitesse, et qu'il ne provoque aucun changement brusque de direction de l'écoulement.

C'est sur les modèles existants de l'évacuateur de crue dn barrage de Bhakra que furent mises au point diverses dispositions du dissipateur d'ónergie, tels que espacement des redans, position et ouverture du secor'd déflecteur, évasement des interstices, etc., etc. Un projet bien au point a ainsi pu être élaboré. Dans certains cas la profondeur des affouillements a été réduite de plus de $90 \%$.
\end{abstract}

\section{INTRODUCTION}

La maitrise des effets des nappes déversantes et, par conséquent, de l'érosion des fonds à l'aval des ouvrages hydrauliques est un problème d'une importance considérable pour l'ingénieur d'irrigation. Dans certains cas, il se forme à l'extré-

\section{ET GAJINDER SINGH}

\author{
M. Sc.
}

Energ!l dissipation below hydraulic structures such as spillways, falls, weirs, etc., is generally brought about by the formation of a hydraulic jump. This requires a certain minimum depth of water at the down'stream end. This may not be obtainable in all cases. A new type of dissipator known as Double Jet Dissipator has been developed.

It is a corrugated deflector with the troughs extended further downstream of the crests to form a second series of deflectors. It is constructed at a suitable point on the slope of a spillway or a fall. Flow taking place down the glacis is split up into a number of jets which interact with each other in the air and dissipate energy. An important feature of the Double Jet Dissipator is that it has neither any part projecting into the high velocity jet nor does it involve any sudden change in the direction of flow.

Different aspects of the energy dissipator such as the spacing of the crests and troughs. position and angle of the second deflector. flare of the extensions, etc., were investigated on the existing hydraulic models of Bhakra Dam over-flow spillway. A suitable design' has been evolved. The experiments have shown this to be very efficient. The depth of scour in some cases has been reduced by over $90 \%$.

\section{INTRODUCTION}

The problem of controlling the action of falling water and consequently the bed scour below hydraulic structures is of paramount importance to an Irrigation Engineer. In certain cases deep scour holes form at the downstream end of the 
milé aval des ouvrages de profondes fosses d'aflouillement. De telles fosses n'apparaissent pas sculement dans des fonds alluviaux, mais ont égalemenl été rencontrées effectivement dans le cas de fonds rocheux (fig. 1). Des frais considérables sont engagés pour la remise en état rréquenle ou l'enlretien de tels ouvrages. works. These scour holes do not occur below works on alluvial beds only but are experienced even in rocky beds (fig. 1). Large sums of money are spent on frequent repairs and maintenance of such works.

For low head dams, weirs, barrages, falls and

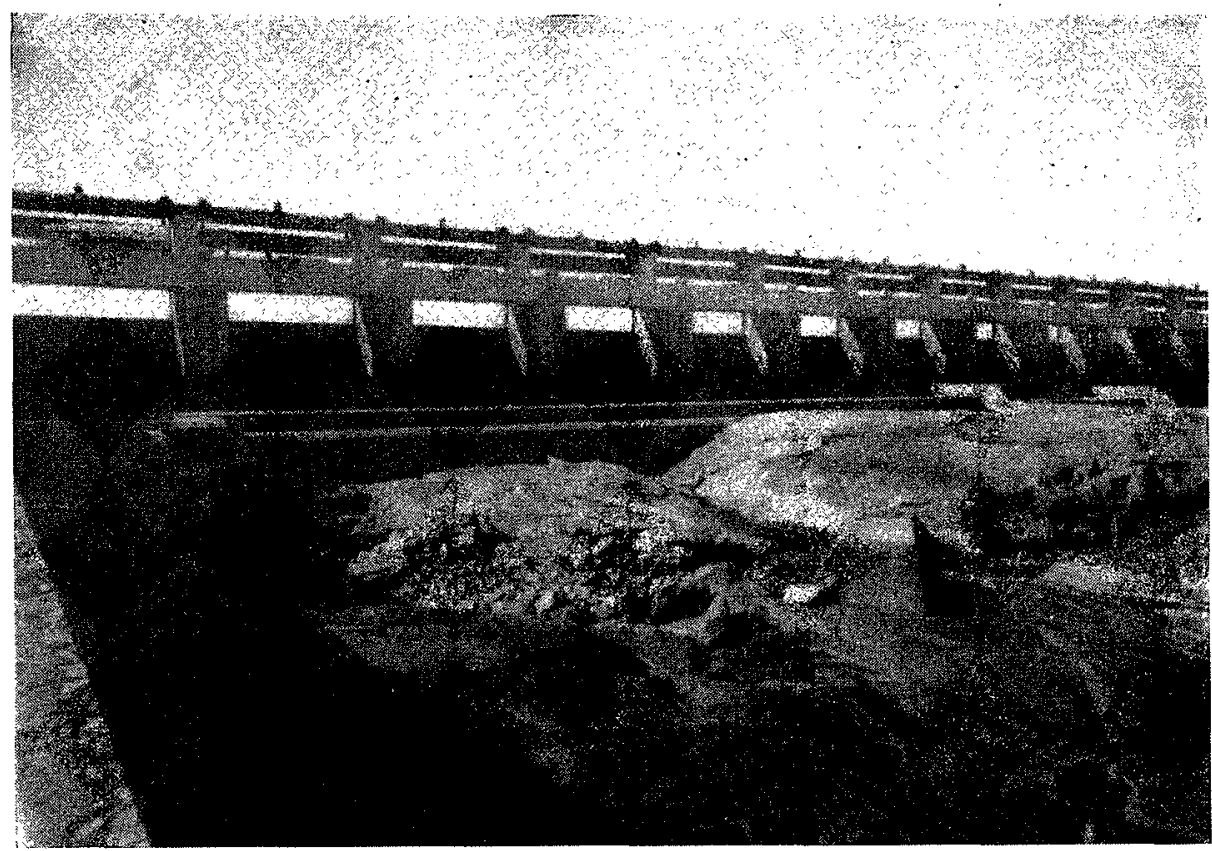

Fig. 1. - Scour hole in rocky bed.

Affonillements dans un lit rochenx.

Pour les ouvrages de basse chute (barrages déversants; seuils; barrages mobiles; ouvrages de chute), on a mis au point et on utilise couramment comme dissipateurs des écrans en maconnerie continus [1] ou discontinus [2], des dents Rehbock [3], des blocs en chicanes [4], etc. Récemment, Narasimham [5] a également réalisé un déflecteur noyé en forme de cuiller qui, construit à l'extrémité du radier aval, provoque une interaction des jets et une redistribution des filets à vitesse élevée; il en résulte une diminution de la profondeur des affouillements. Hamid et Mushrap Ahmed [6] ont mis au point un « aéro dissipateur ». Ils ont recommandé son usage sur les radiers en pente dans la zone du jet à grande vitesse. Il réduit l'action de l'eau dans la cuvette, et par conséquent la profondeur des affouillements à l'aval. Cependant, parmi tous ces dispositifs, le plus efficace et le plus largement répandu est celui qui comporte des redans en chicane. Ils sont disposés au début et à la fin du radier horizontal. Au cours des quinze dernières années, ces redans équipaient pratiquement tous les ouvrages de l'Inde. Ils sont main- level crossings energy dissipating devices such as baffle walls [1], baffle piers [2], Rhebock dentated cill [3], staggered blocks [4], etc. have been evolved and are being used. Recently Narasimham [5] also developed a cup-shape submerged deflector which when constructed at the toe of slope on the Downstream apron, caused the inter-action of jets and redistribution of high velocity filaments; which resulted in the reduction of depth of bed scour. HAMID and MushtaQ Ahmed [6] have developed an Aero Deflector. They have advocated its use on the sloping glacis in the high velocity jet. This diminishes the action of the water in the bucket and consequently reduces the depth of scour downstream.

However, of all these devices, the most efficient and widely used is the staggered blocks. These are constructed at the beginning and end of the horizontal apron. For the last 15 years, the staggered blocks have been constructed practically on all works in India. These have now 
tenant prévus dans les projets et en constituent une partie intégrante.

Dans le cas des ouvrages hydrauliques de haute chute, en raison de la valeur élevée des vitesses en cause, le problème de la dissipation d'énergie devient très difficile. Les dispositifs convenables mis au point jusqu'à présent sont assez rares. Roberts [7] tenta d'y parvenir en fractionnant les jets à grande vitesse à l'aide de blocs de fraclionnement construits sur le parement du barrage. Ce dispositif fut mis au point pour le barrage Loksop en Afrique du Sud. Sur les barrages de haute chute, pourtant, l'action de ces blocs ne s'avère pas satisfaisante car les jets secondaires qu'ils engendrent provoquent dans le lit de la riviere d'importants affouillements.

La dissipation de l'énergie au pied des bar rages élevés est généralement obtenue grâce à un ressaut, ou grâce à une cuvette d'amortissement noyée du genre de celle du Grand Coulee. Enfin, une cuvette non noyée, calée au-dessus du niveau des plus hautes eaux, est parfois adoplée (fig. 2). Cette disposition s'est avérée préféra- been incorporated on the design of works, as an essential part.

In the case of high head hydraulic structures, on account of the high velocities involved, the problem of energy dissipation becomes very difficult. Only a few suitable devices have been developed so far. RobErTs [7] made an altempt to achieve it by splitting up the high velocity jets with the help of "splitters" constructed on the face of dam. These were developed for the Loksop Dam in South Africa. On high dams, however, these splitters do not work successfully as the secondary fall created by the splitters induces deep scour holes in the river bed.

Dissipation of energy below high Dams is usually brought about with the help of Hydraulic Jump Apron or a submerged bucket of Grand Coulee type apron. Besides, a free discharge bucket Fig. 2, located above the highest water level, is sometimes adopted. It has heen preferred at certain places, since it does not form any scour just at the toe of the dam, and also makes space available for the construction of power

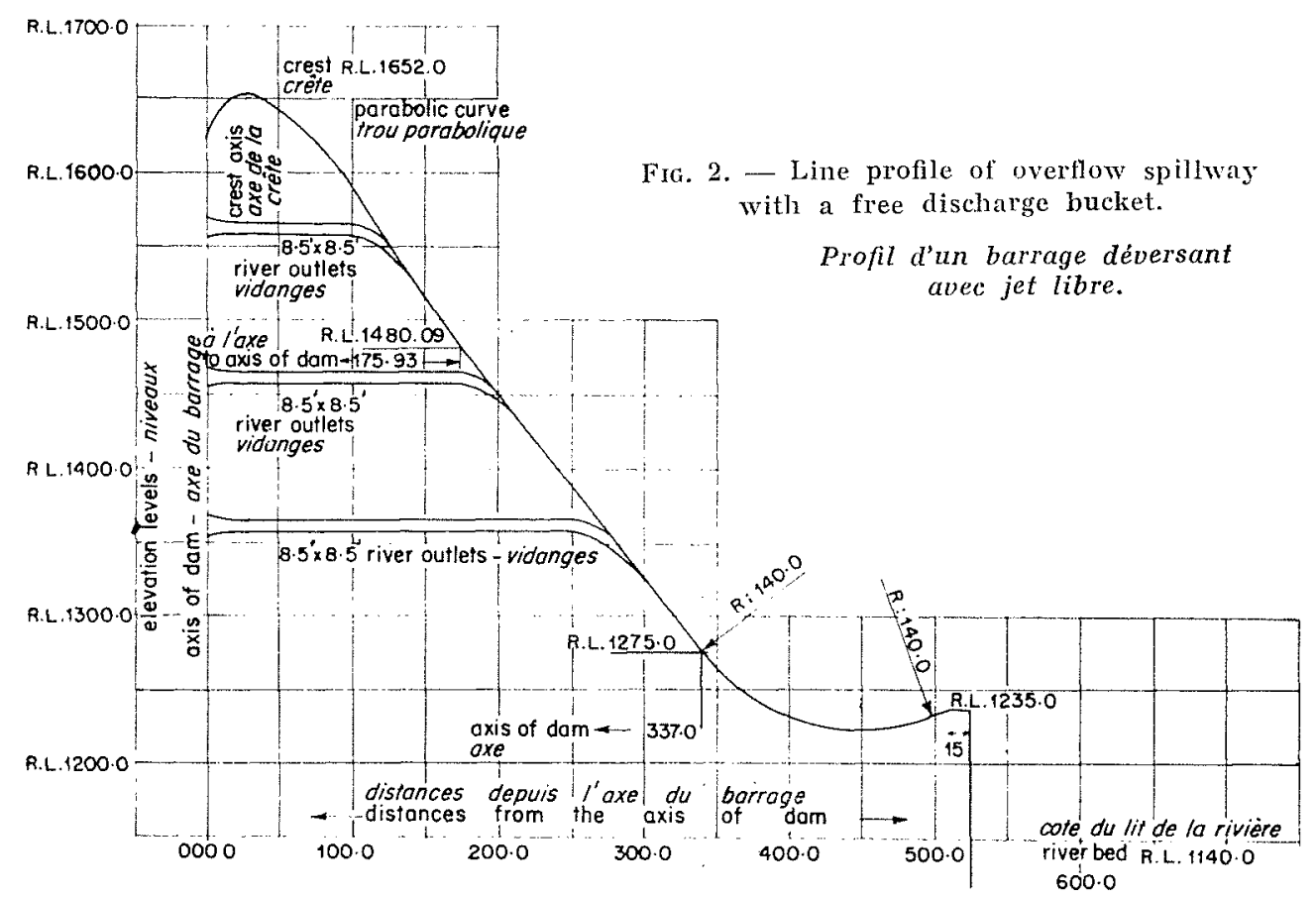

ble dans certains cas, du fait qu'elle évite toul affouillement au pied même du barrage, et réserve ainsi, en dessous, un emplacement pour la construction de la centrale. Cependant, s'il ne se produit pas d'aflouillements importants au pied du barrage, il s'en forme de très profonds un peu plus loin à l'aval, ce qui s'avère également indésirable. Pourtant, si l'on parvient à réduire sensiblement la profondeur de ces affouillements, ce type de seuils dénoyés peut être adopté dans un certain nombre de cas. C'est avec houses underneath. Although no deep scour occurs just at the toe of the dam, very deep scour holes form at some distance downstream, which is considered equally undesirable. If, however, the depth of this deep bed scour could be substantially reduced, the free discharge bucket could be adopted in variety of cases. With this object in view, a series of investigations was carried out both on sinall and large scale models, and a new type of energy dissipators known as double Jet Dissipator, which would eliminate 
cel objectif en vue que fut menée à bien une série d'essais sur modèle à petite et à grande ćchelle, et que fut élaboré un nouveau type de dissipateur, appelé dissipateur à double effet, qui supprime cet inconvénient du seuil dénoyé. L'emploi de ce dispositif peut d'ailleurs heureusement s'étendre au cas du radier avec ressaut et au seuil du type noyé.

\section{LE DISSIPATEUR A DOUBLE EFFET}

Lo déflecteur d'un seuil à jet libre est crenelé. Les interstices réservés entre les redans se pro- this harmful effect of the Free-discharge bucket, was evolved. Besides its use in the free discharge bucket, it could also be successfully adopted on the Hydraulic Jump Apron as well as the submerged bucket type aprons.

\section{THE DOUBLE JET DISSIPATOR}

The deflector of a free discharge bucket at its lree end is corrugated into crests and troughs. The troughs between the crests are extended further downstream to form an other series of deflectors. While the spaces extend downstream

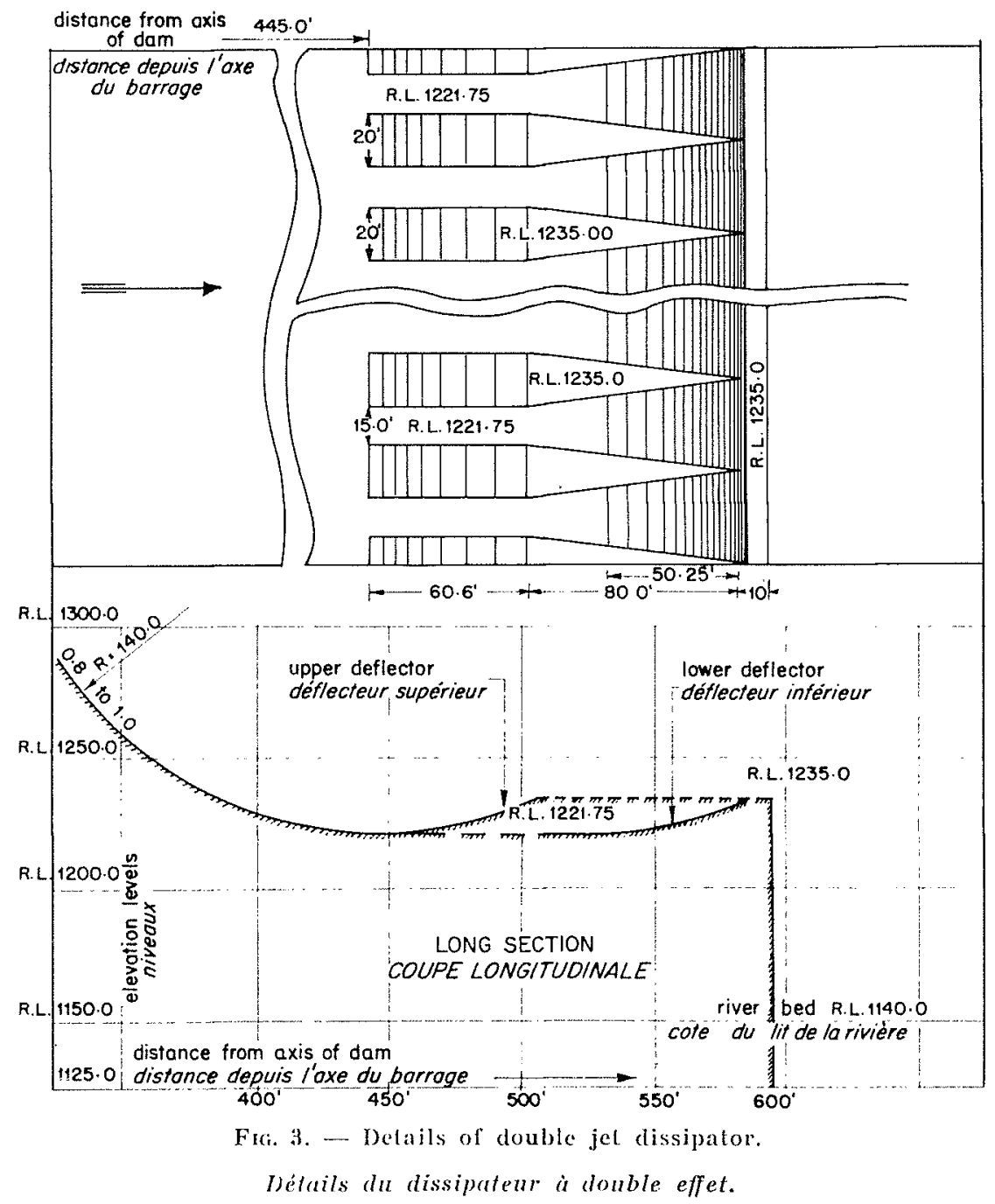

longent vers l'aval de facon à former une nouvelle série de déflecteurs. Tandis que les intervalles s'étendent à l'aval, ils vont en s'élargissant de chaque côté en empiétant de plus en plus sur les crêtes contiguës du déflecteur supérieur (fig. $3,3 a$ et 4 ).

Lorsque. la nappe d'eau à grande vitesse s'écoule le long du parement en pente, elle est they flare out on either side to cover the adjoining crests of the upper deflector (Fig. 3, 3 a and 4).

As the fast moving sheet of water flows down the sloping glacis, a part of it gets deflected at the series of upper deflectors and shoots into the air. A part flows through the troughs, and gels deflected at series of lower deflectors and 


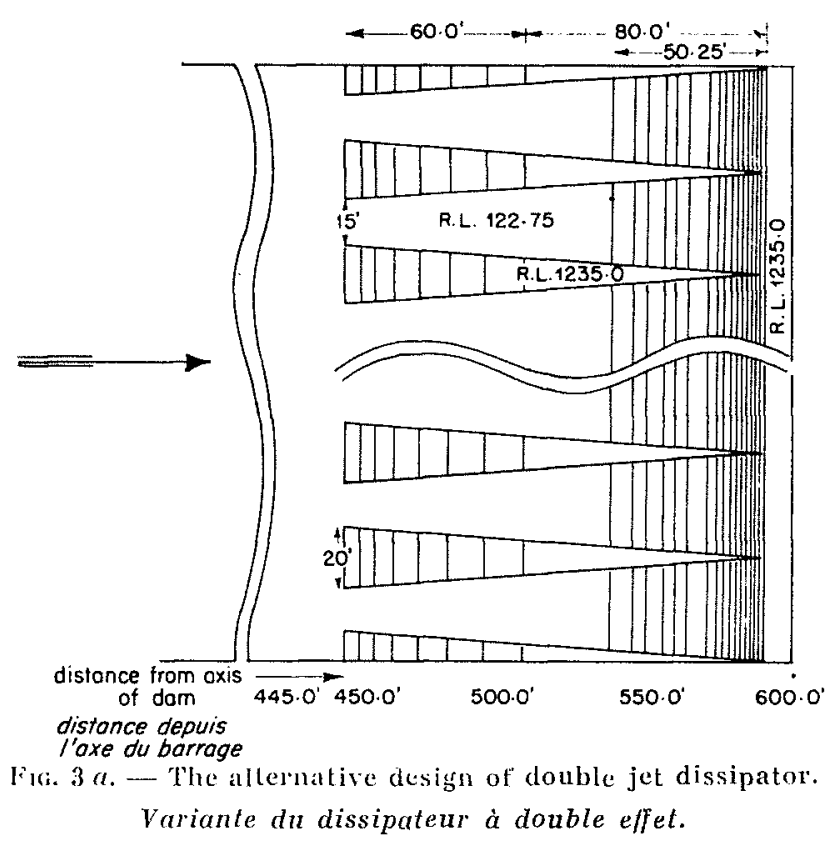

en partie déviće au niveau des déflecteurs supérieurs, et est projetée dans l'air. Une autre partie s'écoule à travers les créneaux, et se trouve déviée par la série des déflecteurs inférieurs, et est projetie dams l'air en jets indépendants. En raison de la forme évasée des créneaux, les jets provenant d'interstices voisins s'interceptent mutuellement. De plus, étant donné que les deux séries de déflecteurs se chevauchent, les jets inférieurs frappent par-dessous ceux qui proviennent des déflecteurs supérieurs. Ainsi les jets issus de deux séries de déflecteurs se dispersent largement, réagissent les uns sur les autres dans l'air, et de cette façon dissipent la plus grande partie de leur énergie en excès. De plus, en se fractionnant ils entrainent une certaine quantité d'air qui, par la suite, réduit les dommages sur le lit de la rivière.

\section{Les études}

Afin de mettre convenablement au point les formes de ce dissipateur à double effet, une série d'essais fut entreprise sur les deux modèles géométriquement semblables existant de l'évacuateur de crue du barrage de Bhakra; l'échelle de ces modèles était respectivement le $1 / 80$ et le 1/44. Le fond du lit était représenté à l'aide d'un matériau granuleux dont le diamètre variait de $1 / 8$ à $1 / 4$ de pouce.

\section{Essai avec un seuil à jet libre}

Les essais portèrent d'abord sur le projet original comportant un seuil à jet libre, ceci dans différents cas de fonctionnement : déversement seul avec les vidanges de fond fermées, puis

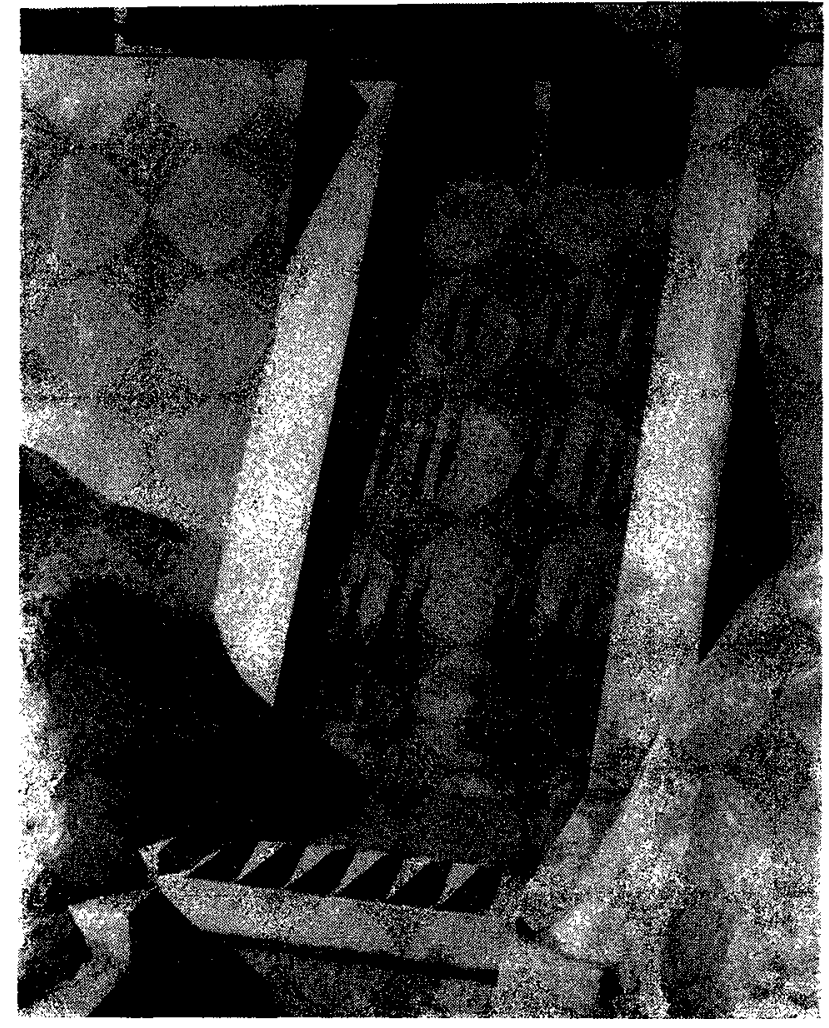

Fig. 4, - The double jet dissipator.

Le dissipateur à double effet.

shoots into air as independent jets. On account of the flaring extensions, jets from the adjacent segments interact with each other. Also since the series of two deflectors are over lapping, jets from the lower end strilse those issuing from the upper deffectors from underneath. Thus the issuing jets from the two series of deffectors, spread out, interact with each other in air and therehy dissipate most of the surplus energy. Besides, while splitting up, a lot of air is entrained which further helps in reducing the action on the bed.

\section{Investigations}

For the purposes of evolving a suitable design of the Double Jet Dissipator, investigations were made on the existing geometrically similar models of Bhakra Dam over flow spillway constructed to a scale of $1 / 80$ and $1 / 44$. The hed was moulded in a granular material of diameter varying from $1 / 8$ to $1 / 4$ of an inch.

\section{Tests with free discharge bucket}

Tests were performed first with the original design of free discharge bucket under two dif- 


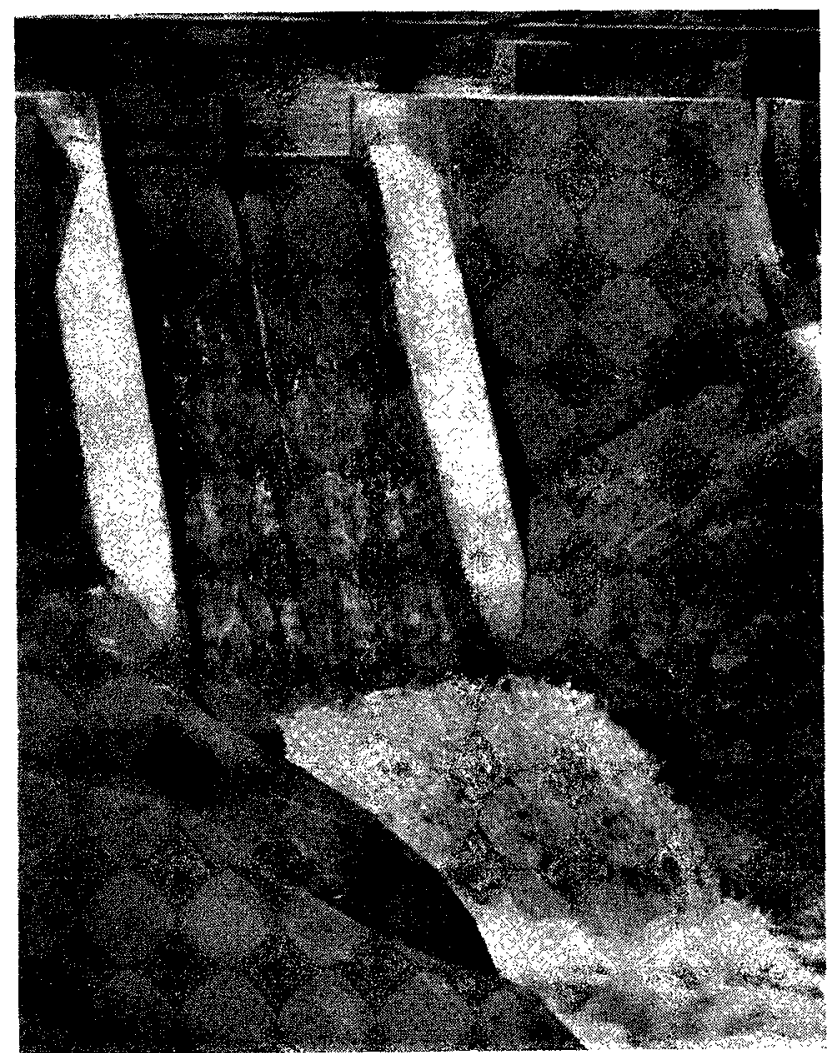

FIG. 5

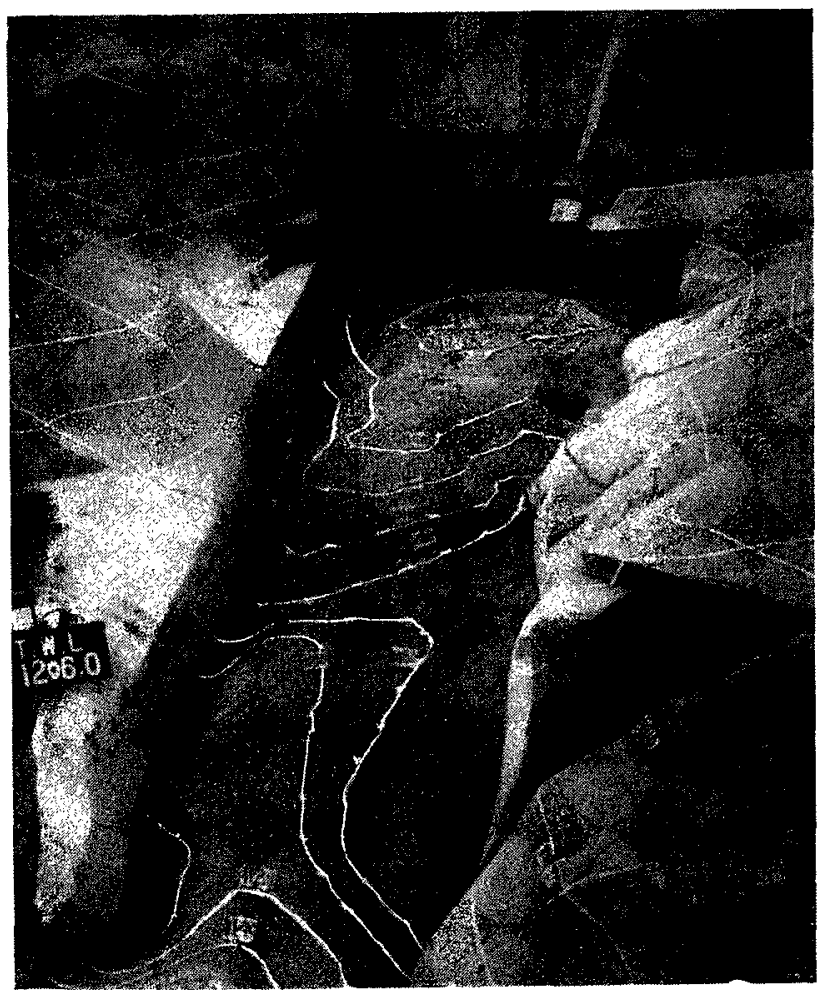

Fici. 7

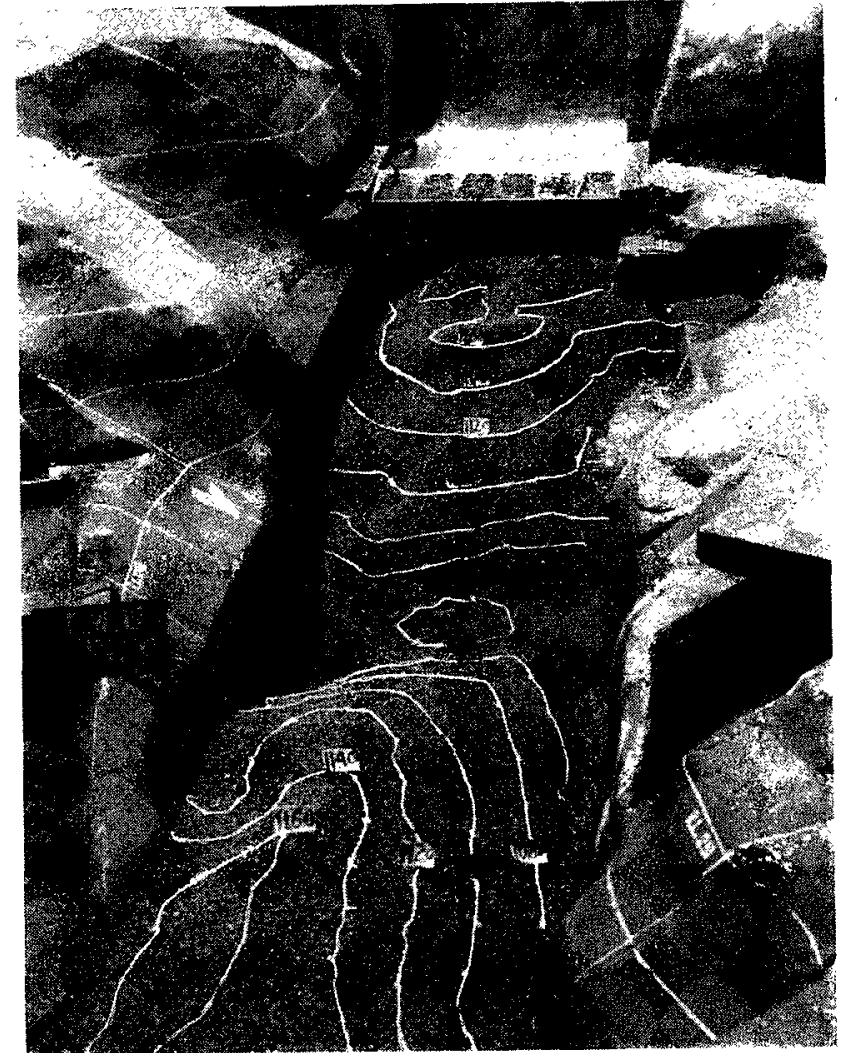

Fli. i

FIG. 5. - Free discharge bucket deflector functioning. L'aspect da jet cn l'absence de dissipateurs.

Fig. 6. - Scour pattern with free discharge bucket deflector. Spillway as well as outlets running. Maximum depth of scour equivalent to $101.5 \mathrm{ft}$.

Affouillements obtenus en l'absence de dissipateurs. Déversement et vidange combinés. La profondeur maximum d'afouillement atteint $101,5 \mathrm{ft}$.

Iidg. 7. - Scour pattern with free discharge bucket deflector, only spillway running. Maximum depth of scour equivalent to 65.0 feet.

Affouillements obtenus en l'absence de dissipateurs. Déversemen't senl. La profondeur maximum d'affouillement atleint $65 \mathrm{fl}$. 
MAXIMUM DEPTH OF SCOUR OBTAINED WITH ORIGINAL SHOOTING BLCKET DEFLECTOR AND DOUBLE JET DSSIPATOR

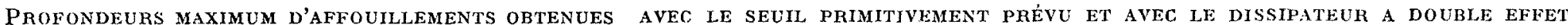

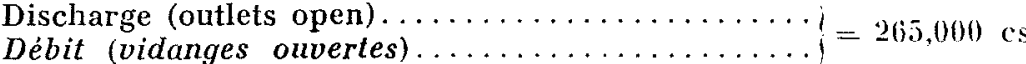

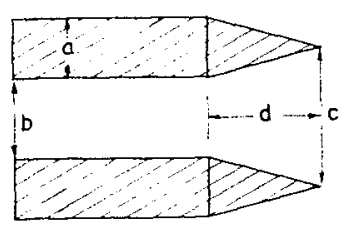

Discharge (outlets closed)................

Débit (vidanges fermées) ..................

Reservoir level......................... 1680.0
Nivean de la retenue

Tail water level. .................... 1206.0

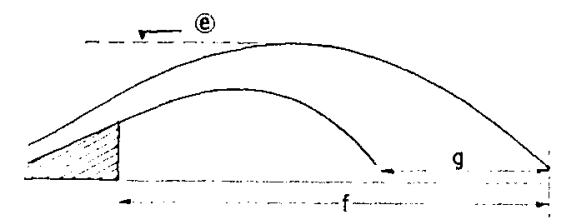

\begin{tabular}{|c|c|c|c|c|c|c|c|c|c|}
\hline $\begin{array}{l}\mathrm{Sr} \\
\mathrm{N}^{\circ}\end{array}$ & $\begin{array}{l}\text { Particulars of experiments } \\
\text { Valenrs caractéristiques }\end{array}$ & $e^{2}$ & $f$ & 9 & $\begin{array}{l}\text { Scour } \\
\text { bed level } \\
\text { Cote de } \\
\text { "affouillement }\end{array}$ & $\begin{array}{l}\text { Depth } \\
\text { of scour } \\
\text { Profondleur de } \\
\text { l'alfonillement }\end{array}$ & $\begin{array}{l}\text { Percentage } \\
\text { reduction } \\
\text { scour depth } \\
\text { Réduction de } \\
\text { la profondeur. } \\
\text { d'affonillement }\end{array}$ & $\begin{array}{l}\text { Position } \\
\text { of scour * } \\
\text { Position } \\
\text { de la fosse }\end{array}$ & $\begin{array}{l}\text { Remarks } \\
\text { Remarques }\end{array}$ \\
\hline 1 & 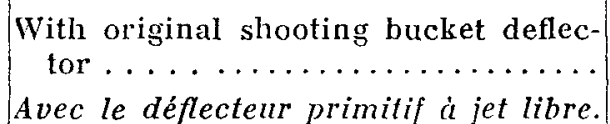 & R.I. 1328.5 & $490 \mathrm{ft}$ & $50 \mathrm{ft}$ & R.L. 1038.5 & $101.5^{\prime}$ & $0.0 \%$ & STA $14 \div 80.0$ & $\begin{array}{l}\text { Outlets open } \\
\text { Vidanges onvertes }\end{array}$ \\
\hline 2 & $-d^{\circ}-\ldots \ldots \ldots$ & R.L. 1322.5 & $510 \mathrm{ft}$ & $50 \mathrm{ft}$ & R.I. 1075.0 & $65.0^{\prime}$ & $0.0 \%$ & STA $12 \div 40.0$ & $\begin{array}{l}\text { Outlets closed } \\
\text { Vidanges fermées }\end{array} \mid$ \\
\hline 3 & $\begin{array}{l}\text { With shooting bucket deflector chang- } \\
\text { ed into double jet dissipator (fig. } 3 \text { ) } \\
\text { Avec le dissipateur } \dot{a} \text { double effet } \\
\text { (fig. 3) } \ldots \ldots \ldots \ldots \ldots \ldots \ldots \ldots\end{array}$ & R.L. 1314.0 & $480 \mathrm{ft}$ & $100-150 \mathrm{ft}$ & R.L. 1090.0 & $50.0^{\prime}$ & $50-74 \%$ & STA $12 \div 40.0$ & $\begin{array}{l}\text { Outlets open } \\
\text { Vidanges ouvertes }\end{array}$ \\
\hline 4 & $-\mathrm{d}^{\circ}-\mathrm{d}^{\circ}-$ alternative design fig. $3 a \ldots$ & R.T. 1320.0 & - & - & R. L. 1079.0 & $61.0^{\prime}$ & $39-90 \%$ & STA $13 \div 20.0$ & $\begin{array}{l}\text { Outlets open } \\
\text { Vidanges ouvertes }\end{array}$ \\
\hline 5 & $\begin{array}{l}\text { Double jet dissipator fig. } 3 \ldots \ldots \ldots \\
\text { Dissipateur } \dot{a} \text { double effet (fig. } 3 \text { ). }\end{array}$ & R.I. 1286.8 & $450 \mathrm{ft}$ & $100-150 \mathrm{ft}$ & R. L. 1109.6 & $30.4^{\prime}$ & $53-23 \%$ & STA $11 \div 40.0$ & $\begin{array}{l}\text { Outlets closed } \\
\text { Vidanges fermées }\end{array}$ \\
\hline
\end{tabular}

* STA : $0.00 \ldots$ the axis of dam

- A partir de l'axe du barrage. 
déversement combiné avec l'écoulement des vidanges de fond (fig. 5).

Dans le cas des vidanges de fond ouvertes, la profondeur maximum d'affouillement obtenue ćtait de 101,5 pieds; lorsque les vidanges de rond étaient fermées, cette profondeur atteignait 65 pieds (fig. 6, fig. 7).

\section{Le dissipateur à double effet}

Les essais furent repris après avoir remplacé le déflecteur original du seuil à jet libre par un dissipatenr à double effet. Les résultats sont donnós dans lo tableau I. La figure 8 montre le dis- ferent conditions of flow viz., only' overflow spillway running outlets closed and overflow spillway as well as outlets runnings (Fig. 5).

Maximum depth of scour obtained with outlets open and with outlets closed were 101.5 feet and 65.0 feet respectively (Figs. 6 and 7 ).

\section{The Double Jet Dissipator}

The deflector of the free discharge bucket was changed into a Double Jet Dissipator and the tests were repeated. Results are given in Table I.

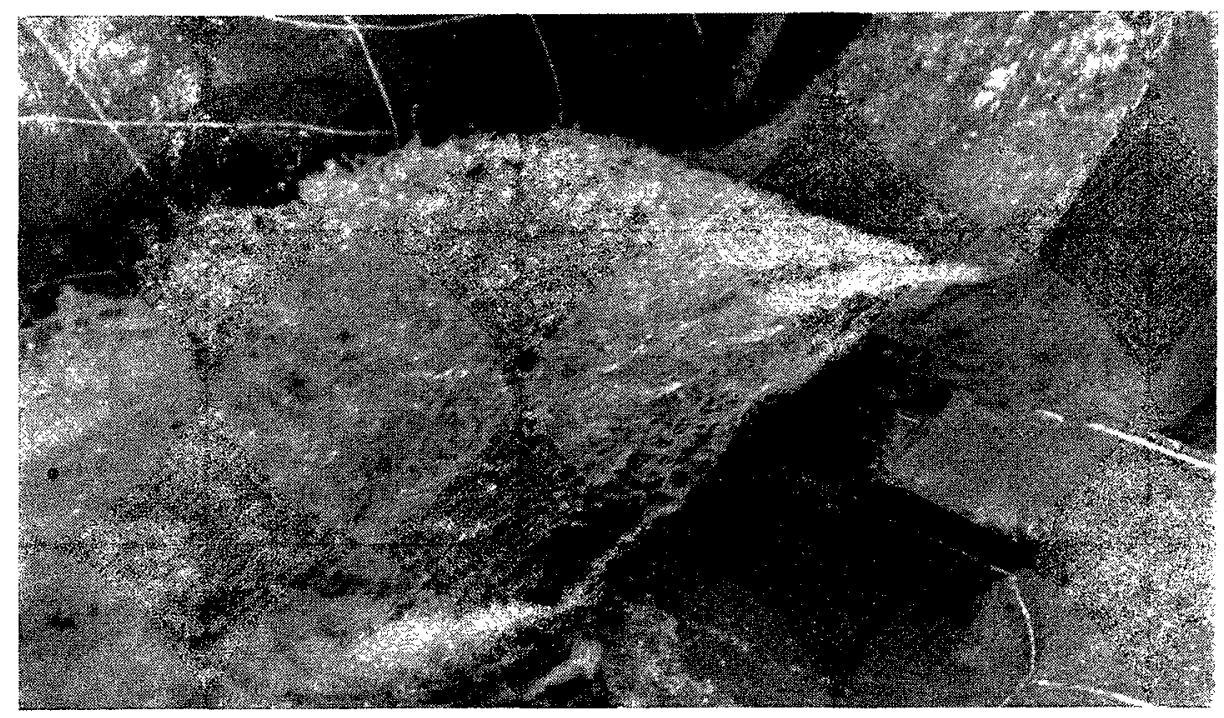

Fig. 8. - Double jet dissipator in operation.

L'aspect du jet avec le dissipateur à donble effel.

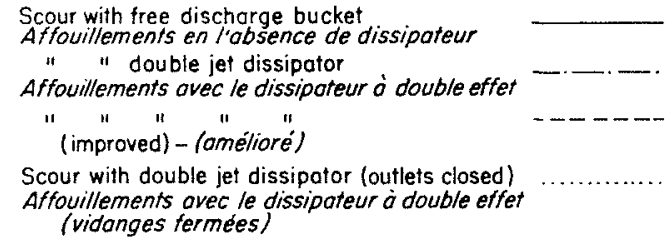

Overflow spillway $\&$ outlets running
Déversement et vidanges combine's
Dischorge $=2,65,000 \mathrm{CS}$
Débit
Reservoir elevation = R.L.1680.0
Cote de remplissage
Toil woter level = R.L. 1206.0
Niveou aval

Overflow spillway $\&$ outlets running Déversement et vidonges combines $=2,65,000 \mathrm{Cs}$ Niveou aval

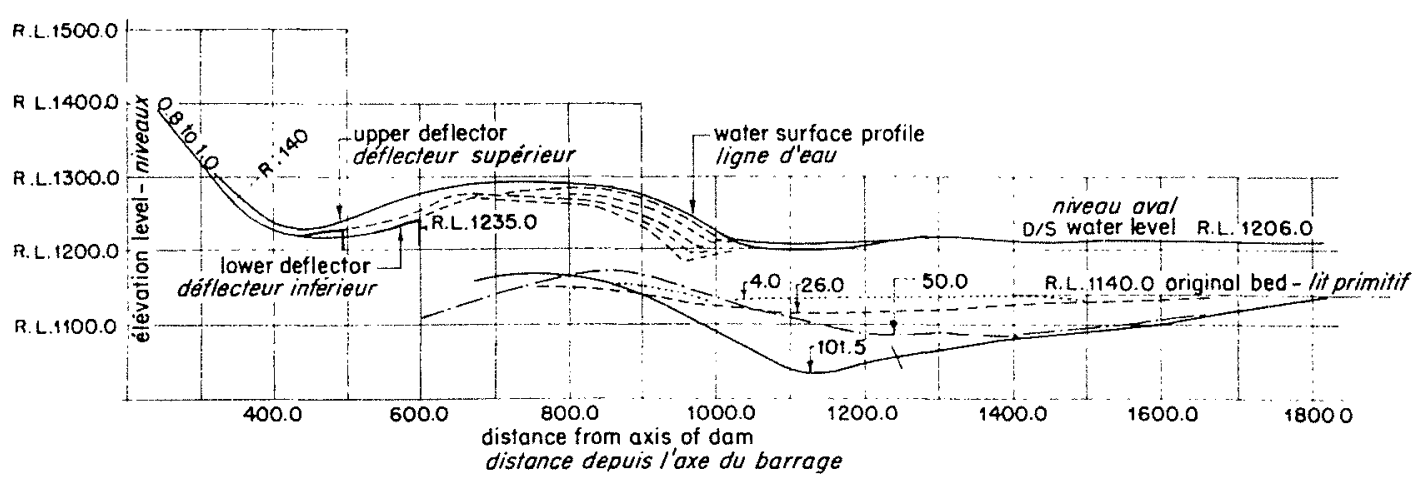

Fig. 9. - Water surface profile and scour obtained with double jet dissipator.

Profil de la surface libre et affouillements obtenus avec le dissipateur à donble effet. 
positif en cours de fonctionnement. A la suite du fractionnement des jets et de l'interaction provoquée par le dissipateur, on put observer ce qui suit :

Une part importante de l'énergie en excès se trouvait dissipée. En conséquence, le niveau atteint par le jet s'abaissa de la cote 1328 à la cote 1314; l'étalement du jet passa de 50 à 100 ou 150 pieds; le jet qui frappait le lit de la rivière sur une longueur de 50 pieds s'y étalait maintenant sur une longueur de 100 ou 150 pieds. Ainsi avec cette nouvelle disposition l'énergie était répartie sur une surface plus grande que dans le premier cas et, par consécuent, la profondeur des affouillements s'abaissait de 101 pieds à environ 50 pieds (fig. 9).

Deux projets différents de dissipateur correspondant aux figures 3 et $3 a$ ont été examinés. La différence entre ces deux projets est que dans le premier les créneaux s'évasaient à partir de l'extrémité des déflecteurs supérieurs, alors que dans le second cas ils commencaient à s'évaser dès l'origine de ces déflecteurs. De ces deux projets celui qui est présenté sur la figure 3 s'avéra le meilleur. L'autre variante fut donc abandonnée.

\section{Les caractéristiques du dissipateur à double effet}

Un certain nombre d'essais complémentaires furent entrepris afin de déterminer :
The functioning of dissipator is shown in Fig. 8. As a result of the splitting up and interaction of the jets brought about by the dissipator, it was observed that :

A major part of the surplus energy was destroyed. Subsequently the rise of the jet decreased from R.L.1328.0 to R.L.1314.0, the spread out of the jet increased from 50 feet to 100 feet150 feet; the jet which used to strike the river bed in a length of 50 feet, now met it in a length of 100 feet to 150 feet. Thus the energy was now distributed over a far greater an area than in the previous case and consequently the depth of scour decreased from 101 feet to about 50 feet. (Fig. 9).

Two different designs of the dissipators (Figs. 3 and $3 a$ ) were examined. The difference in the two was that, in the first one the throughs flare out from the end where as in the sccond case ther start flaring out from the beginning of the upper deflectors. Out of these two, the one shown in Fig. 3 worked better. The alternative design was thus abandoned.

\section{Elements of the Double Jet Dissipator}

Further tests were carried out to determine :

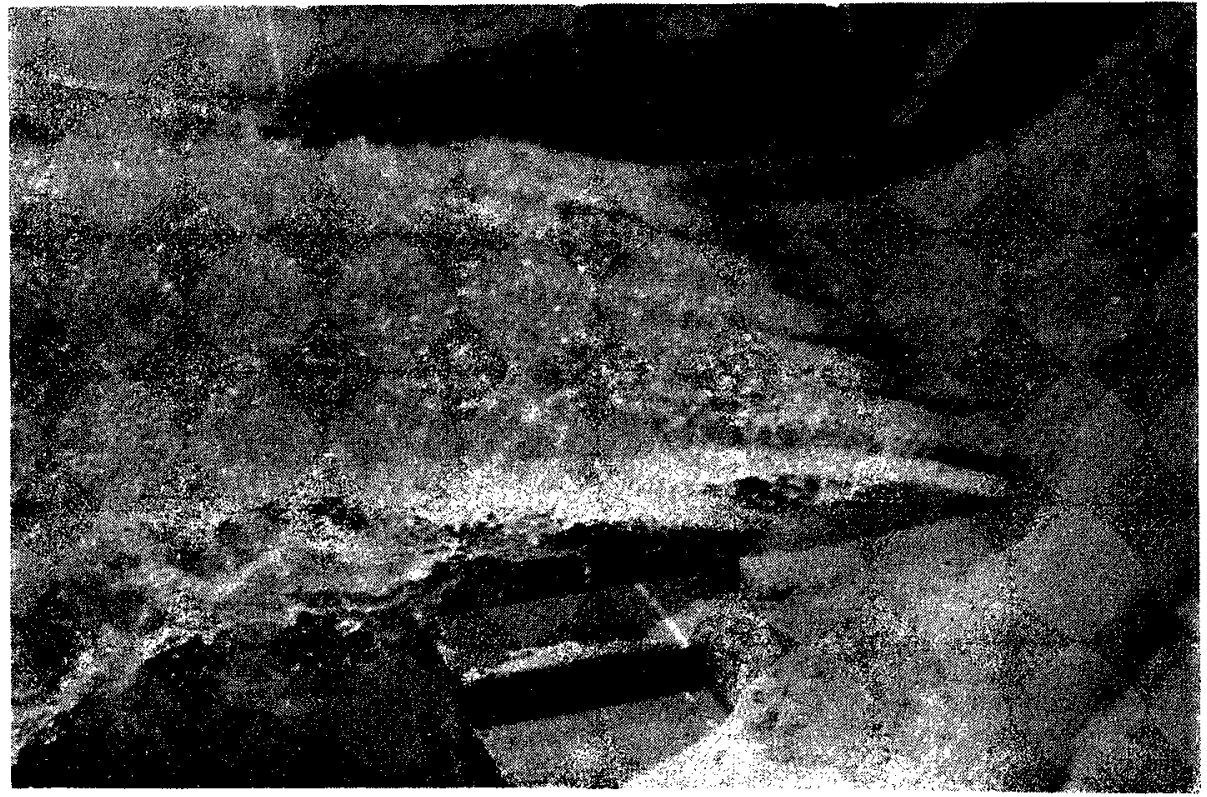

Firi. 10. - Interaction of jets from deflectors constructed at $26^{\circ}$ and $29^{\circ}$ respectively Scour depth obtained : $22.4 \mathrm{ft}$.

inleraction des jets grâce à des défecteurs ayant respectivement $26^{\circ}$ el $29^{\circ}$ d'ouverture. Profondeut d'affonillement oblenue : $22,4 \mathrm{ft}$ 


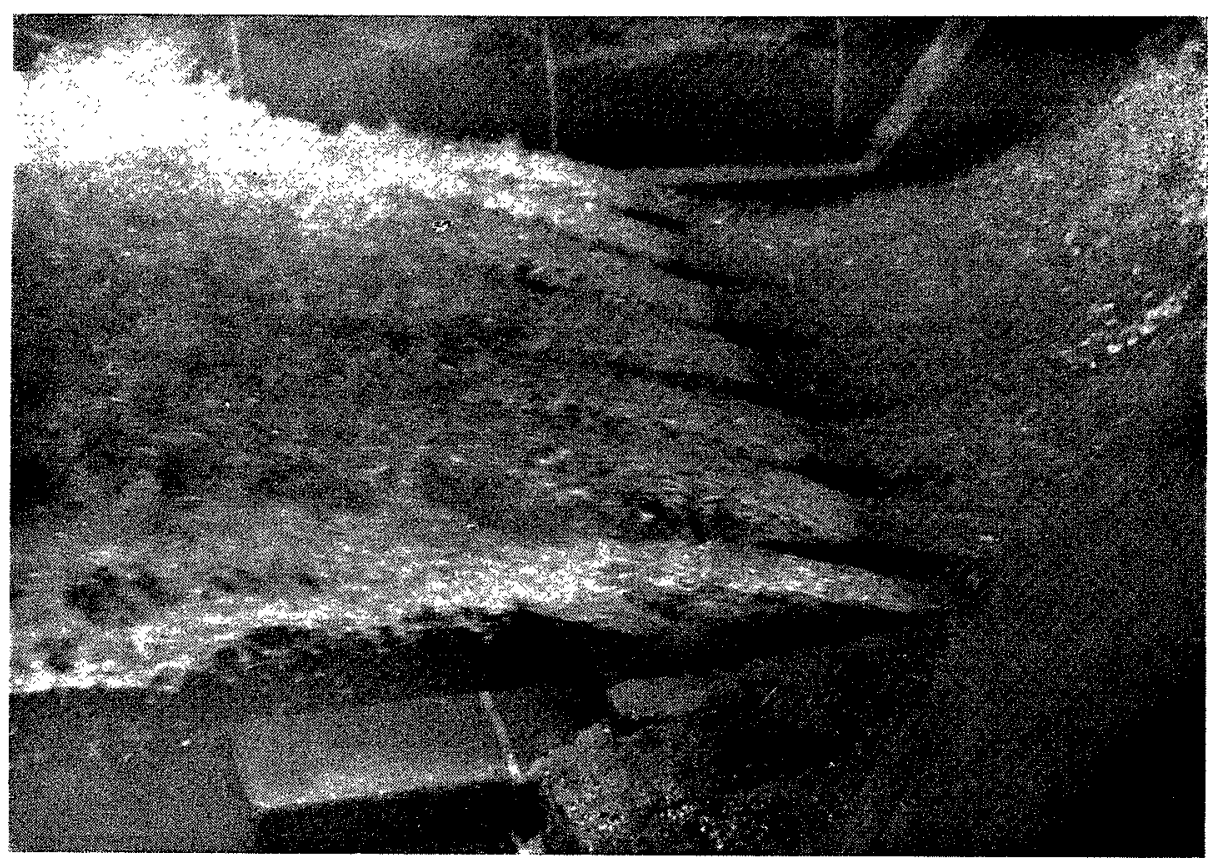

FIG. 11. - Interaction of jets, from deflectors constructed at $26^{\circ}$ and $40^{\circ}$ respectively, appears to be more intense than in figure 10 and jets pierce through each other; yet the dissipation on energy is less. Scour has increased from $22.4 \mathrm{ft}$. to $39.2 \mathrm{ft}$.

Interaction des jets grâce à des déflecteurs ayant respectivement $26^{\circ}$ et $40^{\circ}$ d'ouverture. Cette interaction apparaît plus forte que sur la figure 10 et les jets se pénètrent les uns les autres. Cependant la dissipation d'énergie est moindre. La profondeur d'affouillement est passée de 22,4 ft à 39,2 ft.

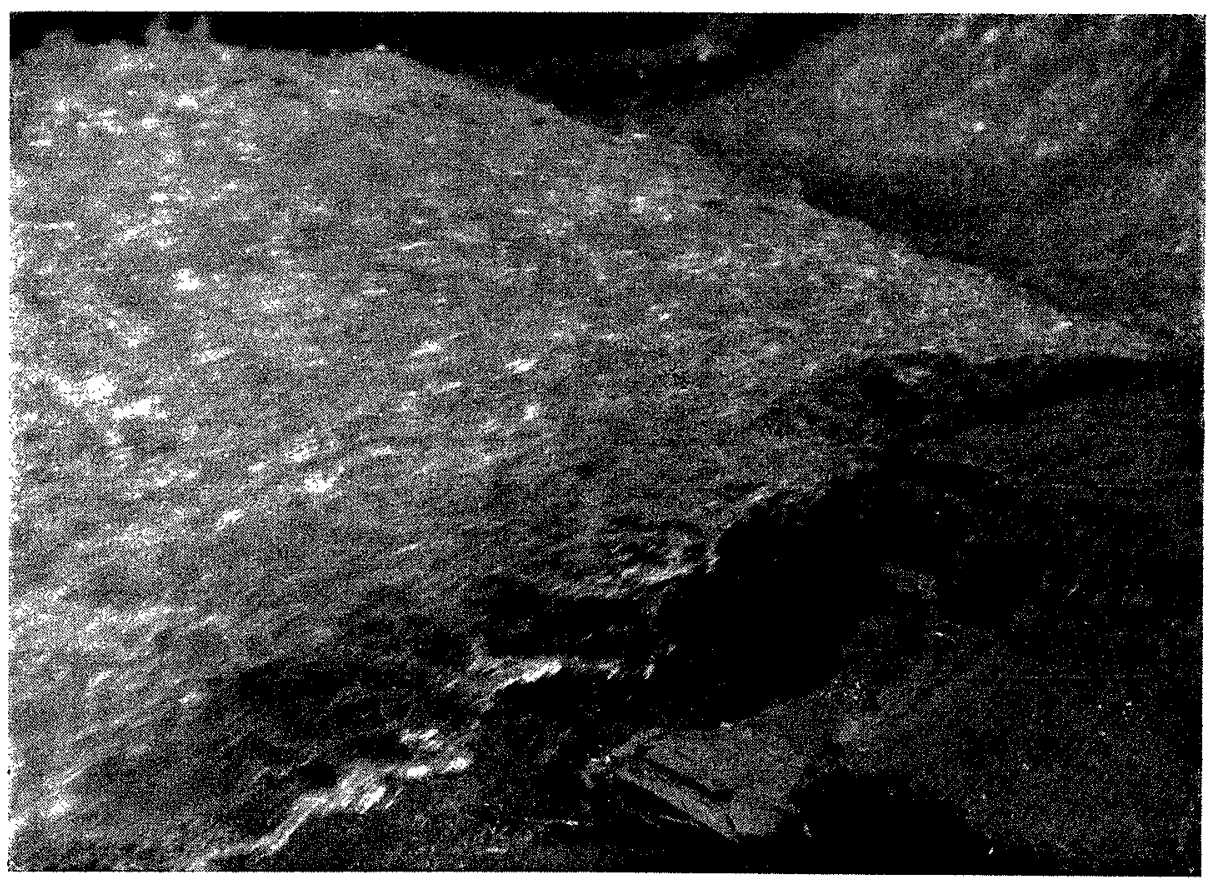

FIG. 12. - Showing most satisfactory type of interaction. Depth of scour: $4.0 \mathrm{ft}$. Le mode d'interaction des jets le plus satisfaisant. Profondeur d'affouillement : 4,0 ft.

$1^{\circ}$ les largeurs respectives des redans et des créneaux du déflecteur supérieur,

$2^{\circ}$ la position du déflecteur inférieur,
1. Suitable widths of the crests and troughs of the upper deflector,

2. Position of the lower deflector, 


\section{Table II}

Tableau II

MAXIMUM DEPTH OF SCOUR OBTAINED WITH DIFFERENT COMBINATIONS OF TROUGHS AND CRESTS OF UPPER DEFLECTOR AND WITH THE LOWER DEFLECTOR AT DIFFERENT POSITIONS

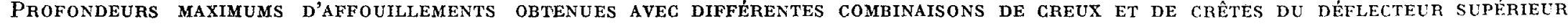
ET DIFFÉRENTES POSITIONS DU DÉFLECTEUR INFÉRIEUR

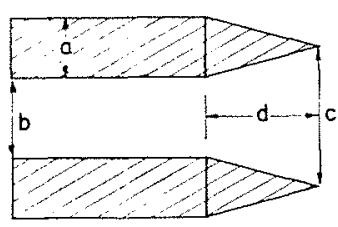

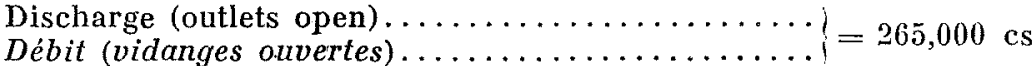

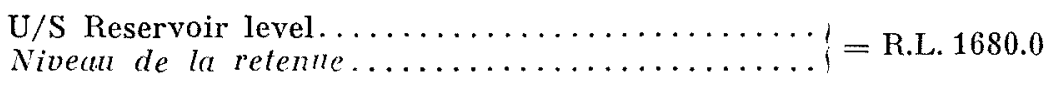

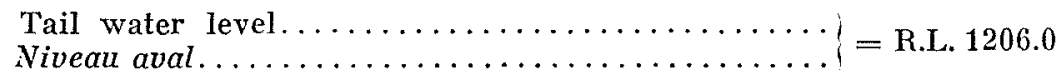

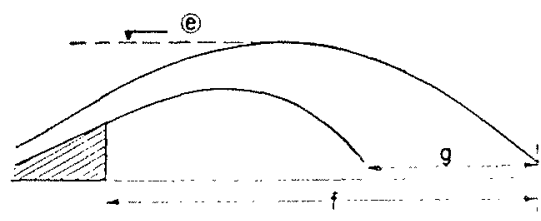

\begin{tabular}{|c|c|c|c|c|c|c|c|c|c|c|c|}
\hline \multirow{2}{*}{$\begin{array}{l}\mathrm{Sr} \\
\mathrm{N}^{\circ}\end{array}$} & \multicolumn{4}{|c|}{$\begin{array}{l}\text { Particulars of experiments } \\
\text { Valeurs caraciéristiques }\end{array}$} & \multirow{2}{*}{$e$} & \multirow[t]{2}{*}{$f$} & \multirow{2}{*}{$g$} & \multirow{2}{*}{$\begin{array}{c}\text { Scour } \\
\text { bed level } \\
\text { Cote de } \\
\text { l'affouillement }\end{array}$} & \multirow{2}{*}{$\begin{array}{l}\text { Depth } \\
\text { of scour } \\
\text { Profondeur de } \\
\text { l'affouillement }\end{array}$} & \multirow{2}{*}{$\begin{array}{l}\text { Percentage } \\
\text { reduction } \\
\text { scour depth } \\
\text { Réduction de } \\
\text { la profondeur } \\
\text { d'affouillement }\end{array}$} & \multirow{2}{*}{$\begin{array}{l}\text { Position } \\
\text { of scour * } \\
\text { Position } \\
\text { de la fosse * }\end{array}$} \\
\hline & $a$ & $b$ & $c$ & $d$ & & & & & & & \\
\hline 1 & $26.5^{\prime}$ & $26.5^{\prime}$ & $53.0^{\prime}$ & $80.0^{\prime}$ & R.L. 1314.0 & $480.0^{\prime}$ & $150.0^{\prime}$ & R.L. 1090.4 & $49.6^{\prime}$ & $51.23 \%$ & STA $12 \div 40.0$ \\
\hline 2 & $20.0^{\prime}$ & $15.0^{\prime}$ & $35.0^{\prime}$ & $\mathrm{d}^{\circ}$ & R.L. 1310.0 & $425.0^{\prime}$ & $200^{\prime}$ & R.L. 1102.0 & $38.0^{\prime}$ & $62.56 \%$ & STA $11 \div 16.0$ \\
\hline 3 & $26.5^{\prime}$ & $26.5^{\prime}$ & $53.0^{\prime}$ & $45.0^{\prime}$ & R.L. 1316.0 & 一 & - & R.L. 1086.8 & $53.2^{\prime}$ & $47.60 \%$ & STA $12 \div 40.0$ \\
\hline 4 & $26.5^{\prime}$ & $26.5^{\prime}$ & $53.0^{\prime}$ & $60.0^{\prime}$ & R. L. 1322.0 & - & - & R.L. 1081.2 & $58.8^{\prime}$ & $42.07 \%$ & STA \\
\hline 5 & $15.0^{\prime}$ & $9.0^{\prime}$ & $24.0^{\prime}$ & $80.0^{\prime}$ & - & - & - & R.L. 1076.8 & $63.2^{\prime}$ & $37.73 \%$ & STA $12 \div 50.0$ \\
\hline 6 & \multicolumn{4}{|c|}{$\begin{array}{l}\text { As in item } n^{\circ} 4 \text { and triangular piers } \\
\text { at the centre of lower deflector. } \\
\text { Comme au } n^{\circ} 4 \text {, mais avec des piliers } \\
\text { an centre du deflecteur inférieur. }\end{array}$} & - & - & - & R.L. 1080.0 & $60.0^{\prime}$ & $40.39 \%$ & STA $13 \div 20.0$ \\
\hline
\end{tabular}

* Due to splashing of water, it is not quite possible to determine with precision the edges of jets. Therefore, values of the rise spread out of the jets given in the table

are approximate values.
${ }_{\text {Par }}$ suite des rejaillissements, il n'est guère possible de relever avec précision les limites des jets. Aussi les valeurs concernant l'étalement des jets sont-elles seulement approximatives. 
Table III

Tableau III

EFFECT OF ANGLES OF THE TWO DEFLECTORS ON THE DEPTH OF SCOUR, etc...

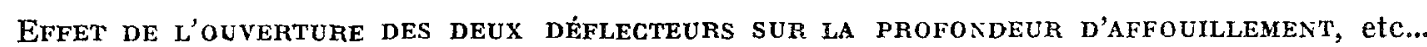

Discharge (outlets open) $\ldots \ldots \ldots \ldots \ldots \ldots \ldots \ldots \ldots \ldots$
Débit (vidanges ouvertes) $\ldots \ldots \ldots \ldots \ldots \ldots \ldots \ldots$

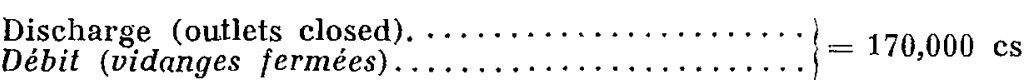

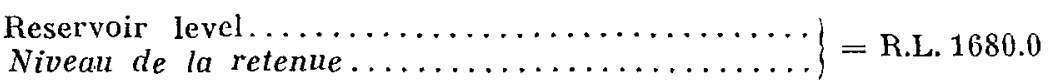

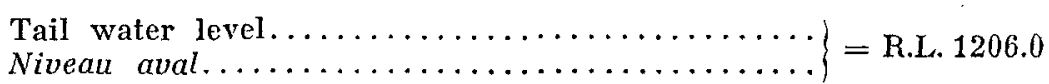

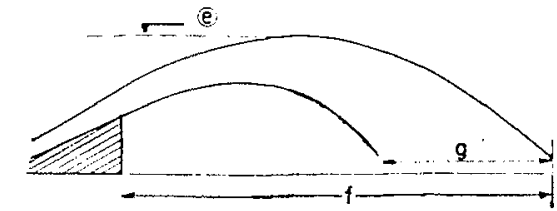

\begin{tabular}{|c|c|c|c|c|c|c|c|c|c|c|c|}
\hline \multirow[b]{2}{*}{$\begin{array}{l}\mathrm{Sr} \\
\mathrm{N}^{\circ}\end{array}$} & \multicolumn{2}{|c|}{\begin{tabular}{|} 
Particulars of experiments \\
Valeurs caractéristiques
\end{tabular}} & \multirow[b]{2}{*}{$e$} & \multirow[b]{2}{*}{$f$} & \multirow[b]{2}{*}{$g$} & \multirow[b]{2}{*}{$\begin{array}{c}\text { Bed level } \\
\text { of scour } \\
\text { Cote de } \\
\text { l'affouillement }\end{array}$} & \multirow[b]{2}{*}{$\begin{array}{c}\text { Depth } \\
\text { of scour } \\
\text { Profondeur de } \\
\text { l'affouillement }\end{array}$} & \multirow{2}{*}{$\begin{array}{l}\text { Percentage } \\
\text { reduction } \\
\text { scour depth } \\
\text { Réduction de } \\
\text { la profondeur } \\
\text { d'reffouillement }\end{array}$} & \multirow[b]{2}{*}{$\begin{array}{l}\text { Position } \\
\text { of scour } \\
\text { Position } \\
\text { de la fosse }\end{array}$} & \multirow{2}{*}{$\begin{array}{c}\text { Max. level } \\
\text { of deposit } \\
\text { against works } \\
\text { Hauteur } \\
\text { maximum des } \\
\text { dépóts entre } \\
\text { les ouvrages }\end{array}$} & \multirow[b]{2}{*}{$\begin{array}{l}\text { Remarks } \\
\text { Remarques }\end{array}$} \\
\hline & \begin{tabular}{|c|} 
Angle \\
upper \\
deflector \\
Ouvert lure du \\
déflecteur \\
supérieur
\end{tabular} & \begin{tabular}{|c|} 
Angle \\
Iower \\
deflector \\
Ouverture du \\
déflecteur \\
inférieur \\
\end{tabular} & & & & & & & & & \\
\hline 1 & $26.0^{\circ}$ & $26.0^{\circ}$ & 1316.0 & $435 \mathrm{ft}$ & $100-150^{\prime}$ & 1080.2 & $59.8^{\prime}$ & $41.08 \%$ & STA $11 \div 60.0$ & 1158.0 & $\begin{array}{l}\text { Outlets open } \\
\text { Vidanges ouvertes }\end{array}$ \\
\hline 2 & $26.0^{\circ}$ & $29.0^{\circ}$ & 1291.0 & $450 \mathrm{ft}$ & $100-150^{\prime}$ & 1117.6 & 22.4 & $65.53 \%$ & STA $10 \div 20.0$ & 1172.8 & $\begin{array}{l}\text { Outlets closed } \\
\text { Vidanges fermées }\end{array}$ \\
\hline 3 & $26.0^{\circ}$ & $33.0^{\circ}$ & 1306.0 & $450 \mathrm{ft}$ & $d^{\circ}$ & 1115.2 & $24.8^{\prime}$ & $61.85 \%$ & STA $11 \div 60.0$ & 1174.0 & $-d^{0}-$ \\
\hline 4 & $26.0^{\circ}$ & $40.0^{\circ}$ & 1320.0 & $450 \mathrm{ft}$ & $100 \mathrm{ft}$ & 1100.8 & $39.2^{\prime}$ & $39.70 \%$ & STA $11 \div 40.0$ & 1182.0 & $-d^{0}-$ \\
\hline 5 & $26.0^{\circ}$ & $22.5^{\circ}$ & 1294.0 & 一 & $100 \mathrm{ft}$ & 1116.0 & $24.0^{\prime}$ & $63.08 \%$ & STA $11 \div 40.0$ & 1175.6 & $-d^{0}-$ \\
\hline 6 & $26.0^{\circ}$ & $13.0^{\circ}$ & 1280.0 & $500 \mathrm{ft}$ & $175-200^{\mathrm{ft}}$ & 1136.0 & $4.0^{\circ}$ & $93.85 \%$ & STA $10 \div 00.0$ & 1160.0 & $-d^{0}-$ \\
\hline 7 & $26.0^{\circ}$ & $13.0^{\circ}$ & - & - & $160 \mathrm{ft}$ & - & $26.0^{\prime}$ & $74.38 \%$ & STA $10 \div 60.0$ & 1164.0 & $\begin{array}{l}\text { Outlets open } \\
\text { Vidanges ouvertes }\end{array}$ \\
\hline 8 & $22.0^{\circ}$ & $33.0^{\circ}$ & 1312.4 & - & $100 \mathrm{ft}$ & 1108.8 & $31.2^{\prime}$ & $51.10 \%$ & STA $11 \div 60.0$ & 1180.0 & $\begin{array}{l}\text { Outlets closed } \\
\text { Vidanges fermées }\end{array}$ \\
\hline
\end{tabular}


$3^{\circ}$ les angles à donner aux déflecteurs supérieur et inférieur.

Un grand nombre de combinaisons différentes de largeur de créneaux et de redans fut examiné. On essaya également diverses positions du déflecteur inférieur. Le tableau II donne les résultats.

En lisant attentivement le tableau II, on voit que le dissipateur fonctionnant de façon la plus satisfaisante comprend un déflecteur inférieur réalisé à une distance de 80 pieds à l'aval, et un déflecteur supérieur ayant pour largeur de redans 20 pieds, et pour largeur de créneaux 15 pieds.

D'autres essais furent entrepris avec divers angles de déflecteurs. On observa la façon dont les jets réagissaient les uns sur les autres, et les profondeurs d'affouillement obtenues. Le tableau III donne les résultats obtenus. Les figures $10,11,12$ montrent les conditions d'écoulement dans trois cas caractéristiques.

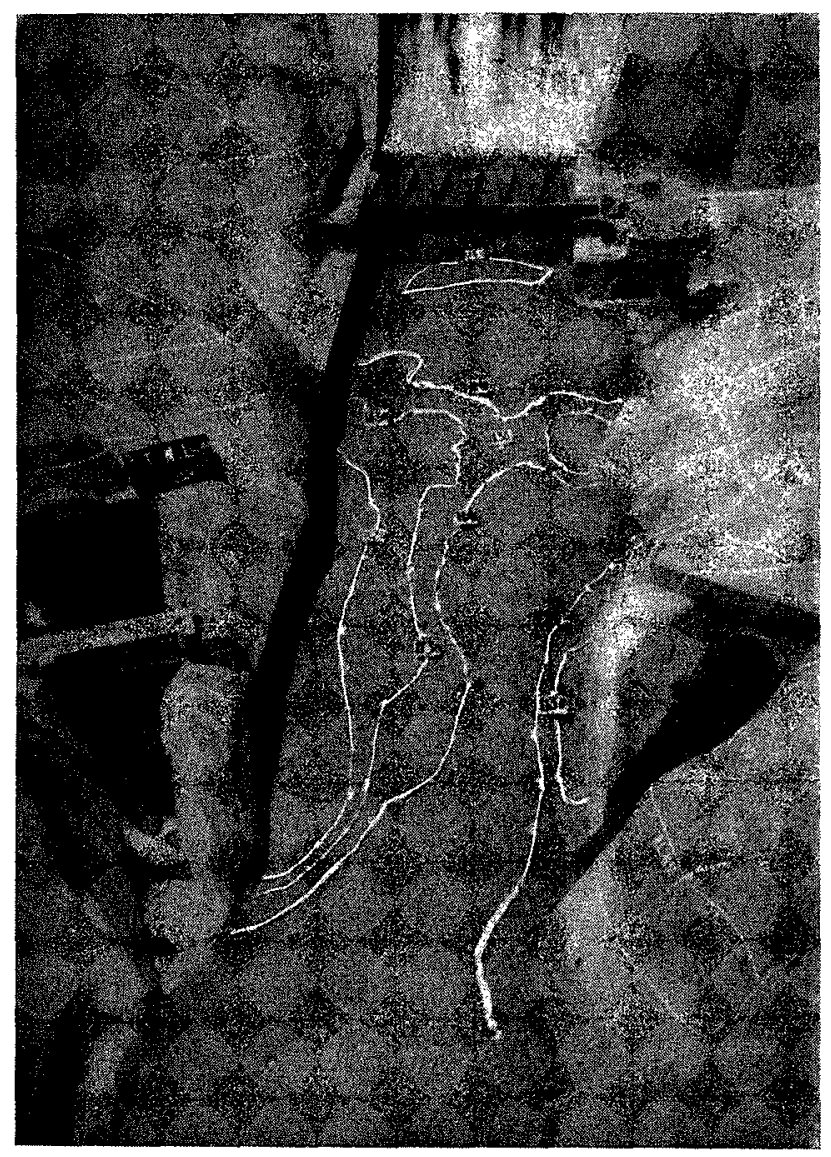

Fig. 13. - Scour pattern with double jet dissipator only spillway running. Maximum depth of scour equivalent to $4.6 \mathrm{ft}$.

Affouillement avec le dissipateur à double effet. Déversement seul. La profondeur maximum d'affonillement atteint $4,6 \mathrm{ft}$.
3. Suitable angles of the upper and lower deflectors.

A number of different combinations of the trough and crest widths were examined. Tests were also made with the lower deflector at different positions. Results are given in Table II.

A perusal of table II indicates that the dissipator with the lower deflector constructed at a distance of 80 feet downstream and the upper deflector with 20 feet width of the crest and 15 feet width of the troughs, worked most satisfactorily.

Tests were further carried out with different angles of the two deflectors. The mode of interaction of the jets and the depth of scour obtained were observed. Results are given in Table III. Condition of flow in three typical

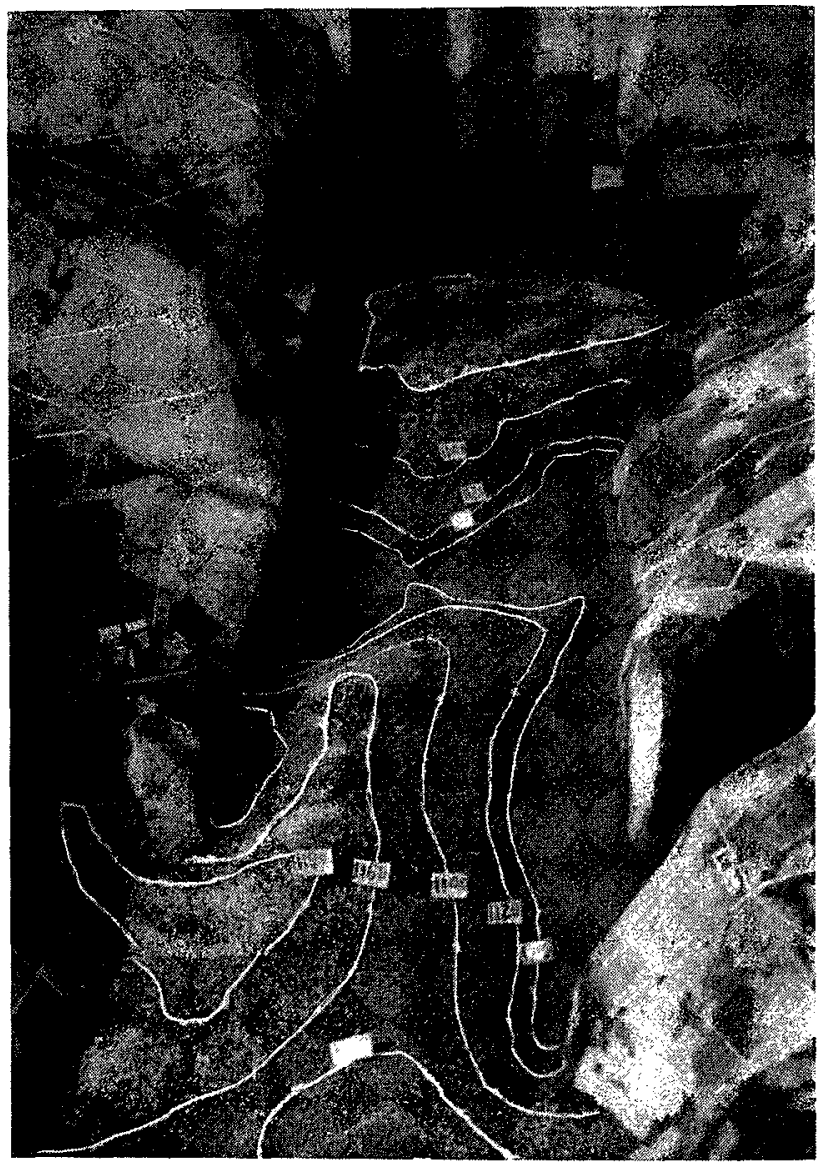

Frg. 14. - Scour pattern with double jet dissipator, spillway as well as outlets running. Maximum depth of scour equivalent to $26.0 \mathrm{ft}$.

Affouillement avec le dissipateur à double effet, déversement et vidange combinés. La profondeur maximum atteint $26,0 \mathrm{ft}$. 
De l'examen de ces figures il résulte que, malgré une interaction des jets paraissant plus intense sur la figure 11 que sur la figure 10, et malgré un chevauchement des jets les uns sur les autres, la dissipation d'énergie est comparativement moins bonne. La profondeur d'affouillement trouvée s'est accrue de 22,4 pieds à 39,4 pieds. Ceci montre que ce n'est pas seulement l'intensité mais le mode d'interaction des jets qui détermine la dissipation d'énergie et finalement la profondeur d'affouillement. La figure 12 montre le type le meilleur d'interaction obtenu lorsque les angles caractéristiques des deux déflecteurs étaient respectivement de 26 et de $13^{\circ}$. Selon que l'on fonctionnait en déversoir seul ou en déversoir combiné avec les vidanges de fond, les affouillements maximum obtenus ont été respeclivement de 4 pieds et de 26 pieds (fig. 13 et 14). cases is shown in Figs. 10, 11 and 12. Examination of these figures shows that although the interaction of jets as shown in Fig. 11 appears to be more intense than the one shown in Fig. 10 and the jets pierce through each other, the dissipation of energy was comparatively less. The depth of scour was found to have increased from 22.4 feet to 39.4 feet. This indicated that, it was not only the intensity, but the type of interaction also, which determined the dissipation of energy and ultimately the depth of scour. The best type of interaction is shown in Fig. 12 and was obtained when the angles of the two deflectors were $26^{\circ}$ and $13^{\circ}$ respectively. The maximum depths of scour obtained with spillway working alone and with spillway and outlets working together were 4.0 feet and 26.0 feet respectively (Figs. 13 and 14).

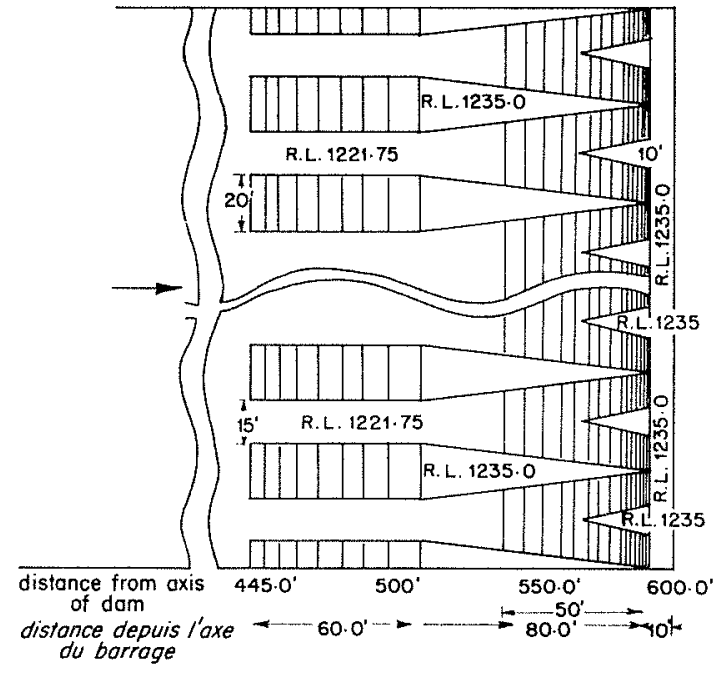

F1r. 15. - Double jet dissipator with triangular piers at the centre of lower deflector.

Le dissipateur à double elfet avec des redans triangulaires supplémentaires au milieu du déflecteur inféricur.

On essaya d'accroître encore le fractionnement des jets et la dissipation d'énergie en construisant des redans triangulaires au centre des déflecteurs inférieurs, comme le montre la figure 15. L'observation montra cependant que ceci n'améliorait pas les conditions de fonctionnement. La profondeur d'affouillement augmentait. De plus, cette disposition avait le sérieux inconvénient de mettre une partie de l'ouvrage directement sous l'action de jets à vitesse hypercritique. Aussi ces dispositions furent-elles rejetées.

On pouvait craindre de voir apparaittre en certains points de l'ouvrage des pressions négalives. Aussi des piézomètres furent-ils installés en un certain nombre de points le long des déflecteurs
An attempt was made at further splitting $u p$ of the jets and increasing the dissipation of energy by the construction of triangular piers at the centre of lower deflectors as shown in Fig. 15. It was, however, observed that it did not improve the conditions. Depth of scour increased. Besides, it had a serious draw back of bringing a part of the structure directly under the action of hyper critical velocity jet. 'This was thus rejected.

It was feared that some negative pressures may not occur at some points of the dissipator. Piezometers were installed at a number of points along the deflectors and along the flaring exten- 
et le long des créneaux. Quelques essais préliminaires furent menés à bien. L'observation montra qu'aucune pression négative n'apparaissait nulle part, et le dissipateur à double effet est donc un ouvrage exempt de cavitation.

\section{CONCLUSION}

Un nouveau type de dissipateur d'énergie appelé dissipateur à double effet a été mis au point. Il provoque une dissipation efficace de l'énergie, et élimine ainsi la formation d'affouillements au pied des seuils déversants des grands barrages et d'autres ouvrages hydrauliques de haute chute. Il peut être utilisé avec succès sur des ouvrages présentant une gamme étendue de hauteurs de déversement.

Outre son application aux seuils à jet libre, il peut aussi être utilisé avec fruit sur les radiers à ressaut ou du type noyé.

Etant donné que le fonctionnement et l'action du dissipateur à double effet sont indépendants du niveau aval, il peut s'avérer particulièrement commode sur les barrages ou ouvrages hydrauliques de haute chute dans le cas des rivic̀res ayant des crues à montée et descente rapides. sions. A few preliminary tests were carried out. It was observed that negative pressures did not occur any where and the Double Jet Dissipator is a cavitation free structure.

\section{CONCLUSIONS}

A new type of energy dissipator known as a Double Jet Dissipator has been developed. It successfully dissipates the energy and thus eliminates the formation of scour at the toe of overflow spillways of high dams and other high head hydraulic structures. It can be successfully used on works of different heights and heads of overflow.

Besides its use on the free discharge bucket, it can also be successfully used on the Hydraulic Jump and submerged bucket type aprons.

Since the working and action of Double Jet Dissipator is independent of tail water level, it can be especially useful on Dams and other high head Hydraulic structures in rivers where the rise and fall of flood levels is rapid.
1. IngLis G. C. - Dissipation of Energy below falls, Government of Bombay, P.W.D. Tech. paper, $n^{\circ} 44$.

2. SteEL I. G. and MANRo R. A. - Baffle piers, experiments on models of Pit River Dams. Proceeding of American Society of Civil Engineers, nov. 1927, part. I.

3. Rневоск Th. - Hydraulic Laboratory Practice, page 184,1929 , edition.

4. Uppat. H. L. and Bhandari N. N. - Protection against scour below river and canal works. Paper $n^{\circ} 214$, Panjab Engineering Congress 1938.

5. NarasimhaM R.K.V. - Dissipators below spillways. I.A.H.R. fourteenth meeting Bombay, 1951.

6. Hamid and Mushtal AHmad. - Aero deflectors for the dissipation of energies.

7. Ronerss D.F., Lt. Col. - The Dissipation of energy of a flood passing over a High Dam. Proc. : South African Soc. of C.E. July 1943. 